\title{
Evaluating Personal Qualifications of Teacher Candidates in Terms of Intercultural Sensitivity Levels*
}

\author{
Gönül Onur Sezer, ${ }^{1, *}$, Pınar Bağçeli Kahraman² \\ ${ }^{1}$ Department of Elementary Education, Faculty of Education, Uludag University, Turkey \\ ${ }^{2}$ Department of Preschool Education, Faculty of Education, Uludag University, Turkey
}

Copyright $\subset 2016$ by authors, all rights reserved. Authors agree that this article remains permanently open access under the terms of the Creative Commons Attribution License 4.0 International License

\begin{abstract}
Teachers first need to participate in cultural activities and must be enthusiastic about improving themselves. It is thought that supporting personal qualifications of teacher candidates through different ways can have positive effects on intercultural sensitivity. The aim of this study is to investigate the relationship between personal qualifications of preschool and classroom teacher candidates and their intercultural sensitivities. Another aim is to determine if there is a relationship between the departments of preschool and classroom teacher candidates, their friends from different countries and their intercultural sensitivity. General screening model was used in this research, which was carried out to determine personal qualifications of preschool and classroom teachers in terms of intercultural sensitivity. The sample of the research was formed of Classroom $(\mathrm{N}-110)$ and Preschool $(\mathrm{N}=103)$ teacher candidates. A personal information form and "Intercultural Sensitivity Scale" were used in the research. The data of the scale were evaluated in terms of normality and the distribution was found normal as a result of Kolmogorov-Smirnov normality test. The distributions of personal qualifications of teachers were evaluated as frequencies and percentages and t-test was used to determine if their departments and foreign friend statuses affected their intercultural sensitivity levels. Furthermore, predictive power of articles that were used to determine the personal qualifications of teacher candidates was analyzed by simple regression analysis. According to the results of the study, it can be said that teacher candidates generally follow activities required by teaching profession that support their cultural developments. It was determined that there is a significant difference on intercultural sensitivity levels of classroom teacher candidates in favor of teacher candidates who express that they have friends from different countries. It was determined that qualifications "Reading cultural books, magazines and newspapers" and "Participating in activities to learn a foreign language" predict teacher candidates' intercultural sensitivities in a positive way.
\end{abstract}

Keywords Intercultural Sensitivity, Personal Qualifications, Preschool and Classroom Teacher

\section{Introduction}

Culture is a notion that may change according to time, policy as well as social and economic developments. It can also exchange with other cultures, take shape and change with developments [13]. The ability to show effective communication behaviors and accomplish goals in a different cultural environment can be defined as Intercultural Communication Competence or Intercultural Efficiency ( [6]; Cited. [21]). The developments in communication ways since 20th century have made individuals, societies and intercultural relationships spread on large areas. Intercultural sensitivity on the other hand is described as developing positive opinions about intercultural relationships, identifying and evaluating cultural differences and developing effective behaviors [21]. Affective dimension of intercultural communication efficiency, intercultural sensitivity comprises four characteristics such as self-concept, open-mindedness, being unprejudiced and social comfort. Open-mindedness is to express oneself clearly and be willing to accept others' opinions; being unprejudiced is to lack prejudices that prevents someone to listen to others ingenuously during intercultural communication; and social comfort is to keep social anxiety at a minimum level during intercultural communication. While self-concept is defined as a self-perception way, self-confidence is related to self-concept and it asserts that individuals with higher self-confidence can communicate with others from other groups or cultures. Individuals with intercultural sensitivity have some characteristics such as self-esteem, self-control, open-mindedness and empathy, which motivate understanding, accepting and approving differences ([6]; [13]; [21]). Egelioğlu and Cetişli [5] indicated that there is a positive relation between empathy level of the students and intercultural sensitivity of them.

In some schools where different cultures can be found together, teachers and students from different cultures continue their educational lives but here may be some problems in these environments because of cultural differences. The most important thing is to have an understanding of education where cultural differences are 
taken into consideration and respected. The most important task is on the shoulders of teachers. Because the ones who run education programs, create educational environments and evaluate all of these are none other than teachers [17]. It is thought that teachers with high personal qualifications who are aware of intercultural differences have more intercultural sensitivity. It is mandatory to create democratic education environments where students respect intercultural differences in order to make students take advantage of equal education opportunities starting from preschool and encourage teachers to give academic and social behaviors to their students [20]. Democratic education environments can only be ensured by noticing and respecting differences. Additionally, teachers with intercultural sensitivity need to possess some skills to gather individuals with different cultural characteristics [17]. It is also emphasized in National Education Basic Law that teachers need to prepare their students for life with strong cultural support [15]. Thus, raising individuals who have intercultural sensitivity is possible by preschool and classroom teachers with intercultural sensitivity. Therefore, teacher candidates need to be supported in educational institutions in order to be sensitive and respective to different cultures. However, teachers first need to participate in cultural activities and must be enthusiastic about improving themselves in order to achieve this. It is thought that supporting personal qualifications of teacher candidates through different ways can have positive effects on intercultural sensitivity. Studies show that teachers who lack the necessary knowledge and skills fail to create new learning environments for students from other cultures ([9]; [7]; [8]). When the body of literature is examined, a study about the effect of personal qualifications of teacher candidates on intercultural sensitivity can't be found. This increases the importance of this study.

For this reason, the aim of this study is to investigate the relationship between personal qualifications of preschool and classroom teacher candidates and their intercultural sensitivities. Another aim is to determine if there is a relationship between the departments of preschool and classroom teacher candidates, their friends from different countries and their intercultural sensitivity.

\section{Method}

\subsection{Research Model}

General survey model was used in this research, which was carried out to determine personal qualifications of preschool and classroom teachers in terms of intercultural sensitivity.

\subsection{Sample}

The sample of the research was formed of Classroom $(\mathrm{N}-110)$ and Preschool $(\mathrm{N}=103)$ teacher candidates studying at Uludağ University Faculty of Education in 2015-2016 academic year.

Demographical information about teacher candidates who participated in the research is shown in Table 1.

Table 1. Demographical Information about Sample Group

\begin{tabular}{|c|c|c|c|c|c|c|c|}
\hline & & \multicolumn{2}{|c|}{ Classroom Teacher } & \multicolumn{2}{|c|}{ Preschool } & \multicolumn{2}{|c|}{ Total } \\
\hline & & $\mathrm{f}$ & $\%$ & $\mathrm{f}$ & $\%$ & $\mathrm{f}$ & $\%$ \\
\hline \multirow{3}{*}{ Gender } & Female & 94 & 85.5 & 91 & 88.3 & 185 & 86.9 \\
\hline & Male & 16 & 14.5 & 12 & 11.7 & 28 & 13.1 \\
\hline & Total & 110 & 51.6 & 103 & 48.4 & 213 & 100 \\
\hline \multirow{3}{*}{ Having different friends } & Yes & 74 & 67.3 & 71 & 68.9 & 145 & 68.1 \\
\hline & No & 36 & 32.7 & 31 & 30.1 & 67 & 31.5 \\
\hline & Total & 110 & 51.6 & 103 & 48.4 & 213 & 100 \\
\hline
\end{tabular}

When Table 1 is examined, it can be seen that $85.5 \%$ of classroom teachers and $88.3 \%$ of preschool teachers are females; while $14.5 \%$ of classroom teachers and $11.7 \%$ of preschool teachers are males. Also, $67.3 \%$ of classroom teacher candidates and $68.9 \%$ of classroom teacher candidates stated that they had friends from other countries. 


\section{Data Collection Tools}

\subsection{Personal Information Form}

A personal information form was used in the research and it composed of questions that were prepared based on articles from the Scale of Teachers' Perceptions on the Cultural Effect of Globalization, which was developed by Seyfi (2006)[18]. The articles were used to determine personal qualifications of teachers regarding increasing effects of globalization and questions were expertized. Personal information form had questions on genders, departments and foreign friend statuses of teacher candidates as well as five point likert type questions designed to determine if the teacher candidates followed cultural publications, participated in cultural activities, learned a foreign language, watched educational-cultural programs and followed websites that would improve their personal developments.

\subsection{Intercultural Sensitivity Scale}

"Intercultural Sensitivity Scale" which was developed by Chen and Starosta[6] and adapted into Turkish by Üstün [21] was used in the research. The original form of the scale that was developed by Chen and Starosta[6] was a five point likert type scale composed of 24 articles and it was formed of five sub-dimensions: Interaction engagement, respect for cultural differences, interaction confidence, interaction enjoyment and interaction attentiveness. However, as a result of a validation study by Üstün [21], the scale was accepted to be a single dimension and it was reduced to 23 articles. While the original form of the scale had .88 as Cronbach Alpha coefficient, the Turkish version had .90 as alpha coefficient. $4^{\text {th }}, 6^{\text {th }}, 19^{\text {th }}$ and $21^{\text {st }}$ articles were removed in the analysis to determine the confidence coefficient in this study and Cronbach Alpha coefficient was determined .74.

\subsection{Data Analysis}

The data of the research was evaluated with SPSS (Statistical Package for Social Sciences) software. The data of the scale was evaluated in terms of normality and the distribution was found normal as a result of Kolmogorov-Smirnov normality test. The distributions of personal qualifications of teachers were evaluated as frequencies and percentages and t-test was used to determine if their departments and foreign friend statuses affected their intercultural sensitivity levels. Furthermore, predictive power of articles that were used to determine the personal qualifications of teacher candidates was analyzed by simple regression analysis.

\section{Findings}

Table 2. Frequency and Percentage Table Regarding Personal Qualifications of Teacher Candidates

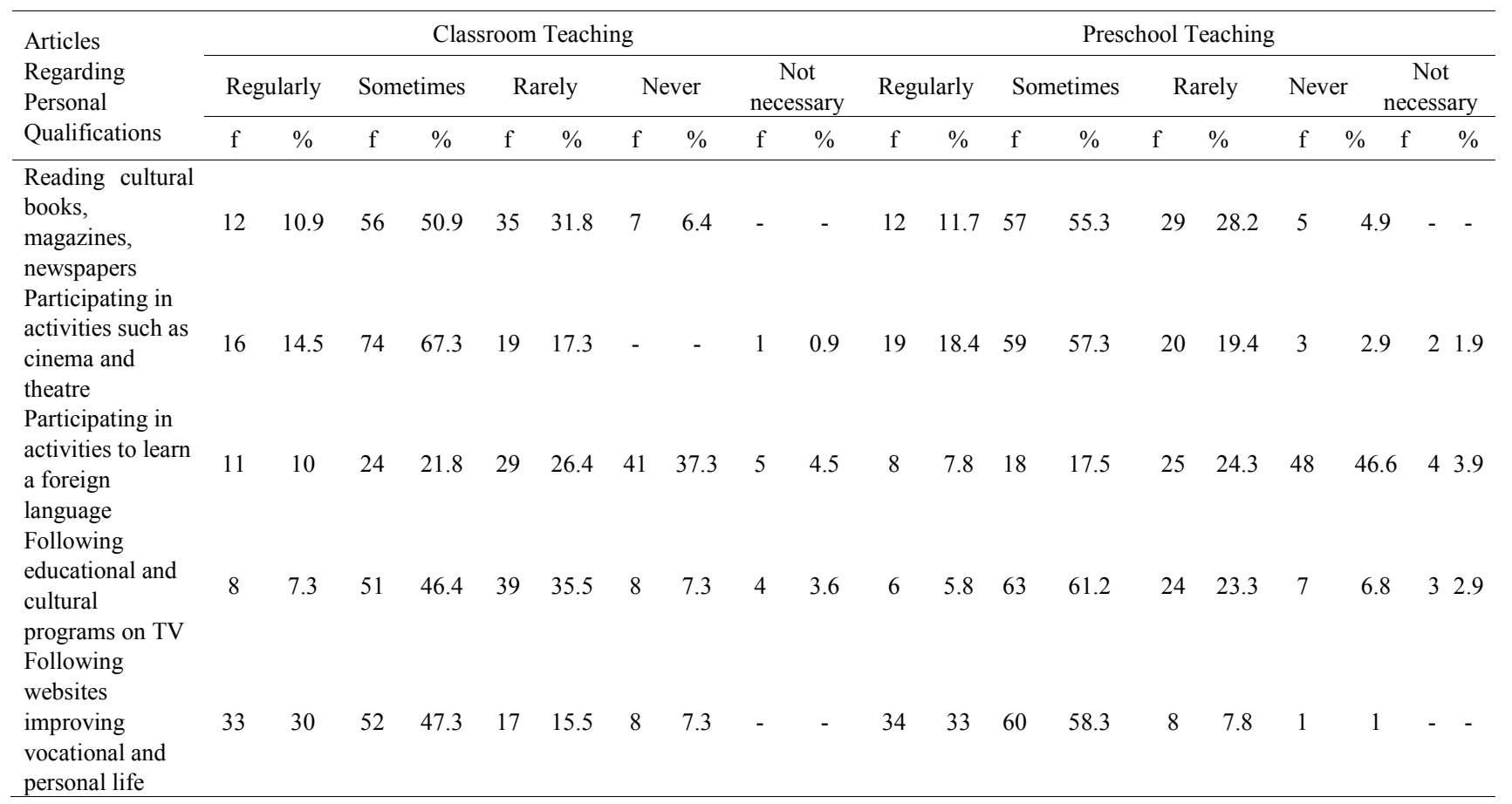


When Table 2 was investigated, it was seen that $50.9 \%$ of classroom teachers and $55.3 \%$ of preschool teachers gave the response "Sometimes" to the article "Reading cultural books, magazines, newspapers". While $67.3 \%$ of classroom teacher candidates and $57.3 \%$ of preschool teacher candidates gave the answer "Sometimes" to the article "Participating in activities such as cinema and theatre", 1 of classroom teacher candidates and 2 of preschool teacher candidates told that they didn't find this personal qualification necessary. While $37.3 \%$ of classroom teacher candidates and $46.6 \%$ of preschool teacher candidates gave the answer "Never" to the article "Participating in activities to learn a foreign language", $10 \%$ of classroom teacher candidates and $7.8 \%$ of preschool teacher candidates told that they participated in them "regularly". While $46.43 \%$ of classroom teacher candidates and $61.2 \%$ of preschool teacher candidates gave the answer "Sometimes" to the article "Following educational and cultural programs on TV", 12 of classroom teacher candidates and 10 of preschool teacher candidates told that they didn't follow them since they didn't find them necessary. As a last article, $47.3 \%$ of classroom teacher candidates and $58.3 \%$ of preschool teacher candidates gave the answer "Sometimes" to the article "Following websites improving vocational and personal life" but 8 of classroom teacher candidates and 1 of preschool teacher candidates told that they "never" followed any of them. It can be seen that answers of classroom and preschool teacher candidates on their personal qualifications are similar. According to these results, it can be said that teacher candidates generally follow activities required by teaching profession that support their cultural developments. However, even if they are not a lot, some teachers don't find these activities necessary and it can be thought that their cultural sensitivities will be at lower levels when they start their professional lives.

As seen in Table 3, there is not a significant difference between the intercultural sensitivity point averages of classroom and preschool teacher candidates in terms of their departments $(t=-1.517, p>.05)$. Although there is not a significant difference between intercultural sensitivity levels of teacher candidates from both groups, it can be said that their intercultural sensitivity levels are high in terms of points to be taken from the scale.

When Table 4 is examined, it can be seen that there is a significant difference between intercultural sensitivity levels of classroom teacher candidates in favor of teacher candidates telling that they have friends from different countries $(t=2.904, p<.05)$. It is seen that there is not a significant difference between intercultural sensitivity levels of preschool teacher candidates in terms of their statuses of having friends from different countries $(t=1.434, p>.05)$. Although intercultural sensitivity levels of teacher candidates of both groups are high, it can be seen that classroom teacher candidates who have friends from different countries have higher point averages than classroom teacher candidates who don't. In another words, it can be said that teacher candidates from the research who have friends from different countries have higher intercultural sensitivity point averages than other teacher candidates who don't have such friends.

Table 3. T Test Results Regarding Intercultural Sensitivities of Teacher Candidates In Terms of Their Departments

\begin{tabular}{|c|c|c|c|c|c|c|c|c|}
\hline & & \multicolumn{4}{|c|}{ Department } & \multirow{3}{*}{$\mathrm{SD}$} & \multirow{3}{*}{$\mathrm{t}$} & \multirow{3}{*}{$P$} \\
\hline & & \multicolumn{2}{|c|}{ Classroom Teach. (n:110) } & \multicolumn{2}{|c|}{ Preschool Teach. (n:103) } & & & \\
\hline & & $\overline{\mathrm{X}}$ & ss & $\overline{\mathrm{X}}$ & ss & & & \\
\hline $\begin{array}{l}\text { Intercultural } \\
\text { Sensitivity } \\
\text { Score }\end{array}$ & Total & 72.59 & 6.02 & 73.86 & 6.22 & 211 & -1.517 & .131 \\
\hline
\end{tabular}

Table 4. T Test Results of Teacher Candidates Regarding Their Statuses of Having Foreign Friends

\begin{tabular}{|c|c|c|c|c|c|c|c|c|c|}
\hline \multirow{3}{*}{$\begin{array}{l}\text { Intercultural } \\
\text { Sensitivity Total } \\
\text { Score }\end{array}$} & \multicolumn{6}{|c|}{ Having Friends from Different Countries } & \multirow{3}{*}{ SD } & \multirow{3}{*}{$\mathrm{t}$} & \multirow{3}{*}{$\mathrm{P}$} \\
\hline & \multicolumn{3}{|c|}{ Yes (n:145) } & \multicolumn{3}{|c|}{ No (n:67) } & & & \\
\hline & $\mathrm{n}$ & $\bar{X}$ & ss & $\mathrm{n}$ & $\bar{X}$ & ss & & & \\
\hline Classroom Teacher & 74 & 73.72 & 5.86 & 36 & 70.28 & 5.76 & 108 & 2.904 & $.004 *$ \\
\hline Preschool Teacher & 71 & 74.44 & 6.48 & 31 & 72.52 & 5.56 & 100 & 1.434 & .155 \\
\hline
\end{tabular}

${ }^{*} \mathrm{p}<.05$ 
Table 5. Regression Analysis Results of Teacher Candidates' Personal Qualifications In Terms of Their Intercultural Sensitivities

\begin{tabular}{|c|c|c|c|c|c|c|}
\hline Predictor Variables & Beta & $\mathrm{t}$ & $\mathrm{R}$ & $\mathrm{R}^{2}$ & Standard Error & $\mathrm{F}$ \\
\hline Reading cultural books, magazines, newspapers & .170 & 2.506 & .170 & .029 & 6.06 & $F^{1}-6.28 *$ \\
\hline Participating in activities such as cinema and theatre & .101 & 1.470 & .101 & .010 & 6.12 & $\mathrm{~F}^{2}=2.160$ \\
\hline Participating in activities to learn a foreign language & .159 & 2.346 & .159 & .025 & 6.07 & $\mathrm{~F}^{3}=.5 .504^{*}$ \\
\hline Following educational and cultural programs on TV & -.110 & -1.604 & .110 & .012 & 6.12 & $\mathrm{~F}^{4}=2.572$ \\
\hline Following websites improving vocational and personal life & .062 & .903 & .062 & .004 & 6.14 & $\mathrm{~F}^{5}=.815$ \\
\hline $\begin{array}{l}\text { Predictor: Attitudes On Intercultural Sensitivities } \\
\text { Dependent Variable: Personal Qualification } \\
{ }^{1} \mathrm{sd}=1, * \mathrm{p}<.05 \\
{ }^{2} \mathrm{sd}=1 \\
{ }^{3} \mathrm{sd}=1, * \mathrm{p}<.05 \\
{ }^{4} \mathrm{sd}=1 \\
{ }^{5} \mathrm{sd}=1\end{array}$ & & & & & & \\
\hline
\end{tabular}

As seen in Table 5, qualifications "Reading cultural books, magazines and newspapers" and "Participating in activities to learn a foreign language" were found important predictors of teacher candidates' intercultural sensitivities in a positive way $(\mathrm{p}<.05)$. Variance explaining ratio of teachers' intercultural sensitivity levels were found .029 in "Reading cultural books, magazines and newspapers" and .025 in "Participating in activities to learn a foreign language". As a result of regression analysis, other variables were not found important predictors in intercultural sensitivities of teacher candidates ( $p>.05)$. According to this result, it can be said that there is a relation between intercultural sensitivities of teacher candidates and reading cultural publications and participating in activities to learn a foreign language.

\section{Discussion, Conclusions and Recommendations}

According to the results of the study, it can be said that teacher candidates generally follow activities required by teaching profession that support their cultural developments. Seyfi[18] determined that teachers with 1-10 years of experience are more interested in cultural activities than teachers with 21 or more years of experience and they are closer to technological information to use the Internet and they pay more attention to the cultural richness of learning a second language.

There is not a significant difference between the intercultural sensitivity point averages of classroom and preschool teacher candidates in terms of their departments. But it can be said that intercultural sensitivity point averages of classroom and preschool teacher candidates are high in terms of point averages that can be taken from the scale. This is promising for both teacher candidate groups. Tertemiz and Aslantaş [19], performed to teacher candidates a project work based on multi-cultural education and examined the effects of this project on teacher candidates' intercultural sensitivity. In this study it was determined that there was no significant difference between the groups. Also, they found that the views of groups about intercultural sensitivity were similar. Similarly, Rengi and Polat[17] stated that intercultural sensitivity levels of teachers are high. Other studies show that there is not a difference on intercultural sensitivity levels of teacher candidates in terms of genders ([10]; [2]; [21]; [16]; [23]). Çoban, Karaman and Doğan [8] determined in their research that teacher candidates doing non-thesis master's degree have positive attitudes towards different cultures.

It was determined that there is a significant difference on intercultural sensitivity levels of classroom teacher candidates in favor of teacher candidates who express that they have friends from different countries, while there is not a significant difference on intercultural sensitivity levels of preschool teacher candidates in terms of having friends from different countries. Banos [1] stated that students who have friends from different cultures have significantly higher intercultural levels than the ones who don't. Also it was determined that intercultural sensitivities of medical and nurse students and teacher candidates who have friends from different countries are significantly different than intercultural sensitivities of others ([21]; [14]). Bekiroğlu and Balc1 [3] stated in their research with students from faculty of communication that students having friends from different cultures cause difference on their intercultural sensitivity levels. Furthermore, they determined that intercultural sensitivity levels of students who want to live in a country with a different culture and know a second language are significantly different.

It was determined that qualifications "Reading cultural books, magazines and newspapers" and "Participating in activities to learn a foreign language" predict teacher candidates' intercultural sensitivities in a positive way. However, it was also determined that other variables such as "Participating in activities such as cinema and theatre", "Following cultural and education programs on TV" and "Following websites improving vocational and personal life" don't predict intercultural sensitivities of teacher candidates. Kaya and Kaya [12] stated in their research that global citizenship perceptions of teacher candidates who know a foreign language are higher than others. Yetiş and Kurt [22] 
determined that Turkish foreign language teacher candidates were high intercultural sensitivity.

In accordance with these results, it can be suggested to do more studies with different working groups and more teacher candidates and contribute to the literature. Furthermore, opinions and attitudes towards intercultural sensitivity can be determined via studies involving qualitative and quantitative methods to study intercultural sensitivity. Practices can be included in courses to increase intercultural sensitivities and personal qualifications in universities.

\section{Note}

*The abstract of this paper was presented at 2nd International Conference on Lifelong Learning and Leadership for All (ICLEL-16), in Liepaja on July, 21-23, 2016.

\section{REFERENCES}

[1] Banos, R. V. (2006). Intercultural sensitivity of teenagers: a study of educational necessities in catalonia. Intercultural Communication Studies. 15 (2): 16-22.

[2] Bayles, P. P. (2009). Assessing The Intercultural Sensitivity of Elementary Teachers in Bilingual Schools in Texas School District. PhD Thesis. The University of Minnesota.

[3] Bekiroğlu, O., ve Balcı, Ş. (2014). Kültürlerarası iletişim duyarlılığının izlerini aramak: iletişim fakültesi öğrencileri örneğinde bir araştırma. Türkiyat Araştırmaları Dergisi, 35, $429-460$.

[4] Büyüköztürk, Ş., Çakmak, E.,K., Akgün, Ö.,E., Karadeniz, Ş. ve Demirel, F. (2011). Bilimsel Araştırma Yöntemleri, 8. bask1, Ankara: PegemA yayıncılık.

[5] Cetişli, N. E., Gülşen, I., Öztornac1, B. Ö., Ardahan, E., Uran, B. N. Ö., Top, E. D., \& Avdal, E. Ü. (2016). Hemşirelik öğrencilerinin empati düzeylerine göre kültürlerarası duyarlılıkları. Izmir Katip Çelebi Üniversitesi Sağlık Bilimleri Fakültesi Dergisi, 1(1), 27-33

[6] Chen, G. and Starosta, W. J. (2000). The development and validation of the intercultural sensitivity scale. Paper presented at the Annual Meeting of the National Communication Association. Seattle, WA.

[7] Cırık, İ. (2008). Çok kültürlü eğitim ve yansımaları. Hacettepe Ĕ̈itim Fakültesi Dergisi. 34, 27-40.

[8] Çoban, A.E., Karaman, N.G., ve Doğan, T. (2010). Öğretmen adaylarının kültürel farklılıklara yönelik bakış açılarının çeşitli demografik değişkenlere göre incelenmesi. Abant İzzet Baysal Üniversitesi Dergisi, 10(1): 125-131.
[9] Gay, G. (2002). Preparing for culturally responsive teaching. Journal of Teacher Education, 53, 106-116.

[10] Hammer, M. R., Bennett, M. J. and Wiseman, R. (2003). Measuring intercultural sensitivity: the intercultural development inventory. International Journal of Intercultural Relations. 27: 421-443.

[11] Karasar, N. (2009). Bilimsel Araştırma Yöntemi 19. Bask1, Ankara: Nobel Yayın Dağıtım.

[12] Kaya, B., ve Kaya, A. (2012). Teknoloji çağında öğretmen adaylarının küresel vatandaşlık algıları. Sakarya University Journal of Education, 2(3), 81-95.

[13] Mahiroğulları, A. (2005). Küreselleşmenin kültürel değerler üzerine etkisi. Sosyal Siyaset Konferansları Dergisi, 50, $1275-1288$

[14] Meydanlioglu, A., Arikan, F. ve Gozum, S. (2015). Cultural sensitivity levels of university students receiving education in health disciplines. Advances in Health Science Education, 20: 1195-1204. doi:10.1007/s10459-015-9595-z

[15] Milli Eğitim Temel Kanunu (1739 Say1l1). (1973). Resmi Gazete (T.24.06.1973, S.14574). Ankara.

[16] Polat, S. ve Barka, T. O. (2012) Multiculturalism and intercultural education: a comparative study with a sample of swiss and turkish candidate teachers. World Applied Sciences Journal, 18 (9): 1180-1189.

[17] Rengi, Ö. ve Polat, S. (2014). Sınıf öğretmenlerinin kültürel farklılık algıları ve kültürlerarası duyarlılıkları. Zeitschrift für die Welt der Türken/Journal of World of Turks, 6(3), 135-156.

[18] Seyfi, T. (2006). Küreselleşme-Kültür İlişkisinin Eğitim Örgütlerini Etkileme Biçimleri (Kayseri ili Örneği), Gazi Üniversitesi Eğitim Bilimleri Enstitüsü Yayımlanmamış Yüksek Lisans Tezi, Ankara.

[19] Tertemiz, N. ve Aslantaş, S. (2016). Çokkültürlü eğitime dayalı proje çalışmasının sınıf öğretmeni adaylarının kültürlerarasi duyarlılık düzeylerine etkisi. Ufuk Üniversitesi, Sosyal Bilimler Enstitüsü Dergisi, 5 (9), 7-22.

[20] Ünlü, İ. ve Örten, H. (2013). Öğretmen adaylarının çokkültürlülük ve çokkültürlü eğitime yönelik algılarının incelenmesi. Dicle Üniversitesi Ziya Gökalp Eğitim Fakültesi Dergisi, (21), 287-302.

[21] Üstün, E. (2011). Öğretmen Adaylarının Kültürlerarası Duyarlılı ve Etnikmerkezcilik Düzeylerin Etkileyen Etmenler, Yıldız Teknik Üniversitesi, Yayımlanmamış Yüksek Lisans Tezi, İstanbul.

[22] Yetiş, V. A., \& Kurt, Ç. (2016). Intercultural sensitivity levels of Turkish pre-service foreign language teachers: Examples from education faculties of two universities in Turkey. Educational Research and Reviews, 11(17), 1719-1730.

[23] Yılmaz, F., ve Göçen, S. (2013). Sınıf öğretmeni adaylarının kültürlerarası duyarlılık hakkındaki görüşlerinin farklı değişkenlere göre incelenmesi. Adıyaman Üniversitesi Sosyal Bilimler Enstitüsü Dergisi, 2013(15). 